\section{Enormously dilated pancreatic duct}

\section{INTRODUCTION}

A diabetic patient presented with $10 \mathrm{~kg}$ weight loss and slightly elevated $\mathrm{C}$ reactive protein without diarrhoea, abdominal pain, fever or leucocytosis. Serum lipase, transaminases, bilirubin, carcinoembryonic antigen and CA19-9 were normal. Ultrasound showed prominent perihilar bile ducts and a cystic mass of the pancreas $(60 \times 57 \mathrm{~mm})$ with echogenic internal structures, which was identified as the main pancreatic duct on endoscopic ultrasound (EUS), without enlarged peripancreatic lymph nodes (figure 1A,B). At endoscopic retrograde cholangiopancreatography (ERCP), the compressed common bile duct was secured by a plastic stent. Cannulation of the pancreatic duct resulted in massive putrid secretion and confirmed an enormously dilated main pancreatic duct over its full length (figure 1C,D).

\section{QUESTION}

What is the most likely diagnosis and what is the next step?

\section{ANSWER}

CT scan demonstrated the pancreatic duct dilatation up to $50 \mathrm{~mm}$ (figure 2A). ERCP showed contrast dye notches due to very viscous mucus, which could be rinsed out together with massive pus (figure 2B). The congested pancreatic and the compressed common bile duct (figure 2C) were splinted by a fully covered $8 \times 60 \mathrm{~mm}$ self-expanding metal stent (fcSEMS) to allow mucus and pus evacuation and an $8 \mathrm{~F}$ double pigtail, respectively (figure 2D). Aspirates from the pancreatic duct exhibited superinfection with Lactobacillus salivarius and Streptococcus salivarius. CT and ERCP were consistent with the diagnosis of main duct intraductal papillary mucinous neoplasm (MDIPMN). Due to the high risk of malignancy (main duct diameter $\geq 10 \mathrm{~mm}$ ), ${ }^{1}$ total pancreatoduodenectomy was performed and confirmed MD-IPMN of adenoma type on histopathology with
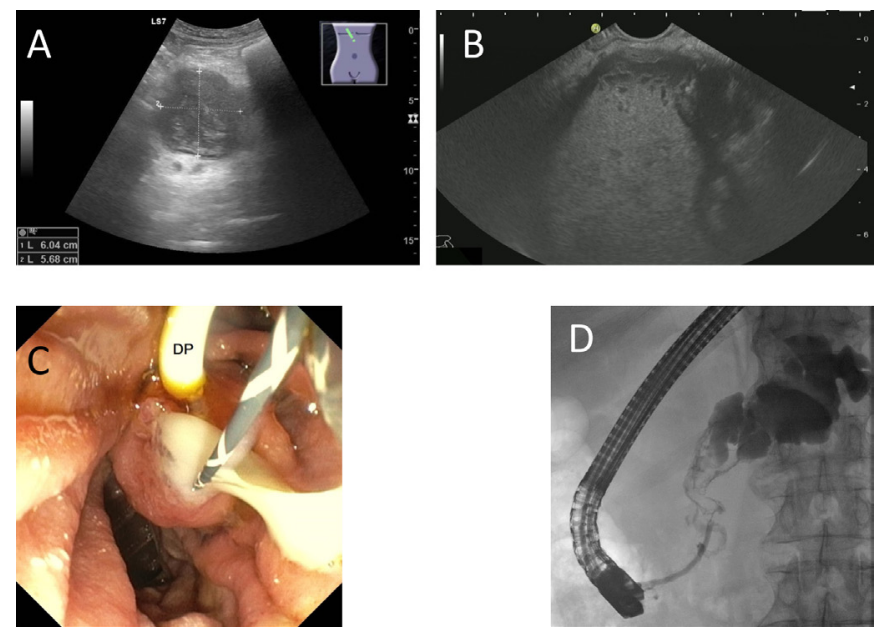

Figure 1 (A) Ultrasound of the pancreas. (B) Endoscopic ultrasound of the pancreas. (C) Endoscopic retrograde cholangio-pancreatography (ERCP) after double pigtail (DP) stent insertion in the common bile duct. Guidewire in pancreatic duct. (D) ERCP shows the dilated pancreatic duct.
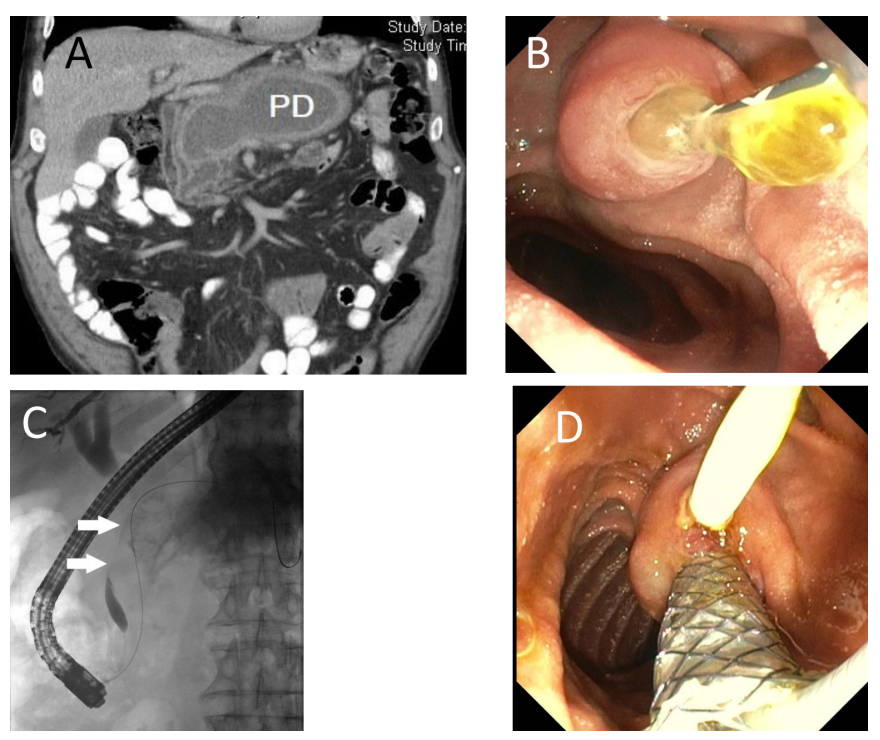

Figure 2 (A) CT shows a massively dilated pancreatic duct (PD). (B) Endoscopic retrograde cholangio-pancreatography (ERCP): papilla after cannulation of the pancreatic duct with efflux of highly viscous mucus. (C) ERCP: compression of the common bile duct (arrows) by the dilated pancreatic duct. (D) ERCP after additional insertion of a fCSEMS in the pancreatic duct.

low-grade dysplasia. The postoperative course and follow-up were uneventful. While mucinous dilatation is the hallmark of MD-IPMN, the characteristic fish mouth papilla was obscured in our patient by massive purulent secretion. Superinfection of IPMN is an extremly rare condition in the absence of fistula ${ }^{2}$ and might have been facilitated by the enlarged orifice and the occluding viscous mucus.

\section{Ronald Koschny $\odot{ }^{1}{ }^{1}$ Matthias Lang, ${ }^{2}$ Thilo Hackert ${ }^{2}$}

${ }^{1}$ Department of Gastroenterology, University of Heidelberg, Heidelberg, Germany ${ }^{2}$ Department of General, Visceral and Transplantation Surgery, Heidelberg University Hospital, Heidelberg, Germany

Correspondence to Dr Ronald Koschny, Department of Gastroenterology, University of Heidelberg, 69120 Heidelberg, Germany;

Ronald.Koschny@med.uni-heidelberg.de

Acknowledgements We thank Dr Martin Ruch (Radiology, Rhine-Main-Centre for Diagnostics, Weiterstadt, Germany) for providing the CT image.

Contributors RK: performed EUS/2.ERCP, wrote manuscript. ML: performed EUS/1.ERCP, wrote manuscript, took care of patient in outpatient setting. TH: wrote manuscript, surgical care. ML/TH: outpatient follow-up.

Funding The authors have not declared a specific grant for this research from any funding agency in the public, commercial or not-for-profit sectors.

Competing interests None declared.

Patient consent for publication Obtained.

Ethics approval We obtained the written consent of the patient to anonymously publish his case.

Provenance and peer review Not commissioned; externally peer reviewed.

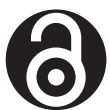

\section{OPEN ACCESS}

Open access This is an open access article distributed in accordance with the Creative Commons Attribution Non Commercial (CC BY-NC 4.0) license, which permits others to distribute, remix, adapt, build upon this work non-commercially, and license their derivative works on different terms, provided the original work is 


\section{Editor's quiz: GI snapshot}

properly cited, appropriate credit is given, any changes made indicated, and the use is non-commercial. See: http://creativecommons.org/licenses/by-nc/4.0/.

(C) Author(s) (or their employer(s)) 2021. Re-use permitted under CC BY-NC. No commercial re-use. See rights and permissions. Published by BMJ.

\section{(D) Check for updates}

To cite Koschny R, Lang M, Hackert T. Gut Epub ahead of print: [please include Day Month Year]. doi:10.1136/gutjnl-2021-324335

Received 8 February 2021

Revised 14 April 2021

Accepted 15 April 2021
Gut 2021;0:1-2. doi:10.1136/gutjnl-2021-324335

ORCID iD

Ronald Koschny http://orcid.org/0000-0003-2117-9137

\section{REFERENCES}

1 European Study Group on Cystic Tumours of the Pancreas. European evidence-based guidelines on pancreatic cystic neoplasms. Gut 2018;67:789-804.

2 Watanabe K, Karasaki H, Mizukami Y, et al. Cyst infection of intraductal papillary mucinous neoplasms of the pancreas: management of a rare complication: report of 2 cases. Pancreas 2014;43:478-81.

3 Kondo H, Naitoh I, Okumura F, et al. Clinical features of acute obstructive suppurative pancreatic ductitis: a retrospective review of 20 cases. J Gastroenterol Hepatol 2016;31:1366-73. 